\title{
Preparatory stage for instrumental monitoring and structural inspection of buildings and structures
}

\author{
Yurii Aleksandrovich Novikov \\ Department of Geodesy and Photogrammetry \\ Industrial University of Tyumen \\ Tyumen, Russian Federation \\ novikov.tiu@gmail.com
}

\author{
Vera Nikolaevna Shchukina \\ Department of Geodesy and Photogrammetry \\ Industrial University of Tyumen \\ Tyumen, Russian Federation \\ shukina82@mail.ru
}

\begin{abstract}
In the context of dense urban development, it is challenging to assess possible risks for buildings and structures being influenced by construction work, especially in the historical part of the city where historical and cultural properties and architectural monuments are located [10-12]. The paper presents observation and test methods to determine criteria of structural assessment of buildings being influenced by construction work. The paper describes the preparatory stage to monitor structural state of the listed buildings of federal importance: the Trinity Monastery and the building of former Commercial School in Tyumen. Vertical and horizontal displacements and tilts, which are measured by geodetic methods and modern geodetic equipment, are the main parameters for structural assessment of buildings being influenced by construction work. To define a set of parameters and to choose the needed measuring methods and tools is an urgent task, which requires practical tests, taking into account the specific features of the building [3-9].
\end{abstract}

Keywords- monitoring of structural state, settlement marks, tilt, deformations

\section{INTRODUCTION}

The most significant and interesting monuments of temple architecture are located in the historical part of any ancient city of Russia, and Tyumen is no exception. First, these are the buildings of the Trinity Cathedral, the Church of Peter and Paul, the Rector's Corps, the Church of the Exaltation of the Holy Cross, etc.

Modern buildings and engineering facilities are being built in the immediate vicinity of the listed buildings.

One of the most ambitious projects in the city's history was launched in 2010 - the construction of the Tura River embankment to strengthen the right bank, landscape and beautify the architectural look of the central part of the city.

The working project of bank protection includes the following technical solutions:

- $\quad$ filling the back wall with imported soil reinforced with geotechnical grid; Reno mattresses and MAK-MAT roll material are placed on the soil;

- $\quad$ making a trench drain from box-shaped gabions;
- $\quad$ using a ready peat-sand mixture with seeds of grass plants which is laid on a pre-installed geogrid to accelerate formation of grass cover.

When choosing the system of bank protection, geotechnical modeling was carried out to study performance of the right bank of the Tura River. This work was carried out by the Institute for North Development of the Siberian Branch of the Russian Academy of Sciences. The results obtained make it possible to determine that stability of the slope is ensured when it is fixed with gabions strengthened with filling in the direction of the river-bed.

The need to carry out geotechnical monitoring was considered at the stages of pre-project and project control of construction works to apply timely checks of the state of buildings under construction and existing facilities.

In 2016, construction work began near the listed buildings of federal importance: Trinity Monastery (Fig. 1) located in 10, Communisticheskaya St. and the building of former Commercial School (Fig. 2), now the building of Industrial University of Tyumen located in 2, Lunacharskogo St.

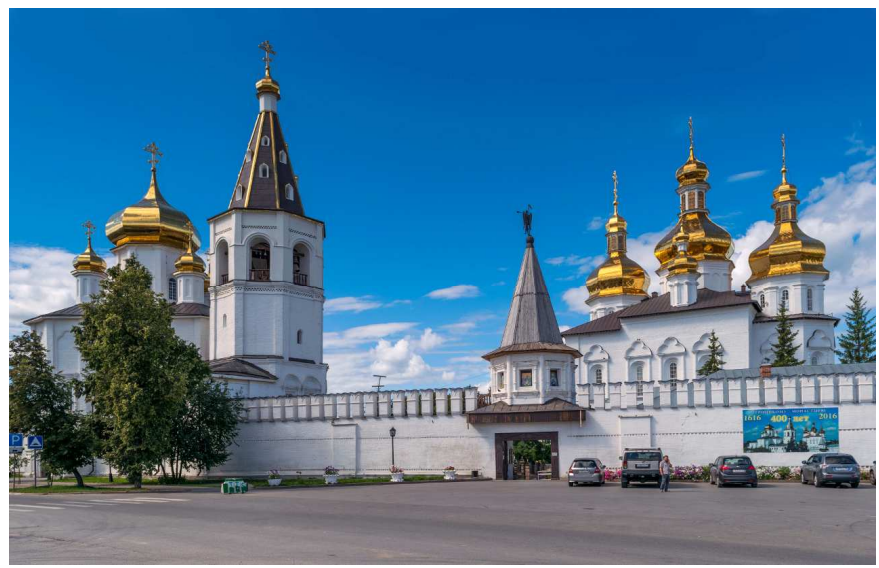

Fig. 1 Trinity Monastery 


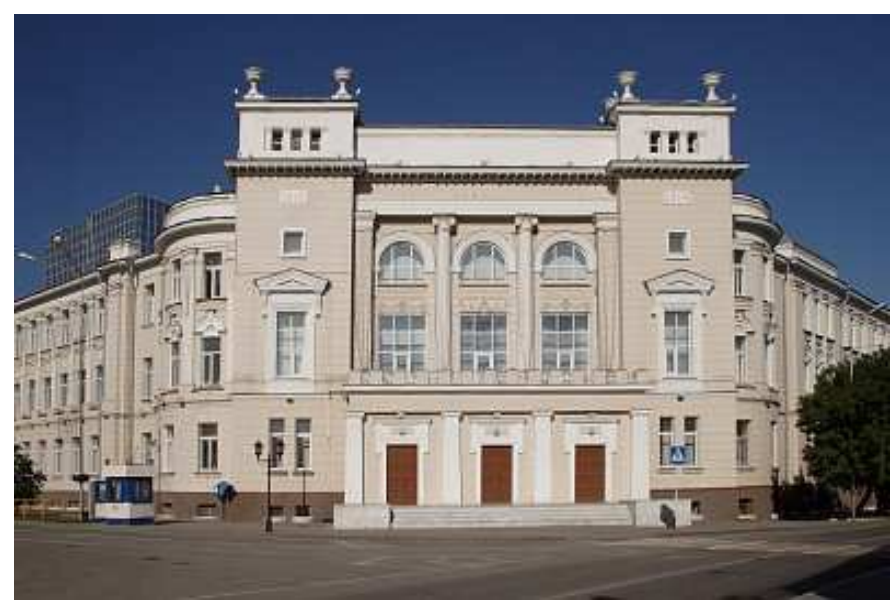

Fig. 2 Building of former Commercial School

Ultimate limit values of extra settlements, differential settlements and tilts are the main parameters for safe construction work in the immediate vicinity of the buildings under monitoring. These parameters should not be exceeded when performing all types of construction work at the site [1].

Safety of the structures under monitoring is ensured if the following requirements are met:

- The total extra settlements of buildings, relative difference in settlements and tilts must be within the characteristic values depending on the structural state.

- Acceleration of foundation vibrations in the buildings under monitoring should be within the limits of background values measured prior to commencement of basic construction works.

- Gain in the width of crack growth should not exceed $1 \mathrm{~mm}$.

In order to ensure that sitework meets the specified final requirements, the intermediate requirements are needed to be introduced.

The intermediate requirements showing errors in sitework are as follows:

- The total settlement reaches $3 / 4$ of the ultimate limit settlement and more.

- Acceleration of ground vibrations which exceed background values.

- Regular gain in the width of crack growth which exceeds $0.5 \mathrm{~mm}$ per month.

Monitoring and structural inspection of buildings being influenced by construction work are carried out to control satisfaction of the given requirements.

The monitoring mode can be regular or urgent depending on the impacts on heritage properties.

As a rule, the first cycle of monitoring should be preceded by structural inspection of heritage properties and surrounding buildings.

\section{RESULTS}

When surveying the area around the Monastery and the building of Commercial School, the specialists from NGO "TyumGASU" found out defects caused by differential settlements, slope processes and the dynamic impacts due to immersion of sheet piles and construction of a pile field in strengthening and improving the slope of the right bank of the Tura River [2].

Due to the high historical value of the Trinity Monastery and the building of Commercial School, it was preliminary determined that the buildings under survey were in a limited operating condition; the $3^{\text {rd }}$ category of the structural state of all buildings was adopted in accordance with GOST R 561982014.

The intervals between the cycles of monitoring and normative values of the ultimate additional deformations of foundations for the $3^{\text {rd }}$ category of structural state of the listed buildings of federal importance are presented in Table 1 [14].

TABLE 1 PARAMETERS OF MONITORING

\begin{tabular}{|l|l|}
\hline \multicolumn{1}{|c|}{ Parameters of monitoring } & \multicolumn{1}{c|}{$\begin{array}{c}\text { Value of the parameter of } \\
\text { monitoring }\end{array}$} \\
\hline $\begin{array}{l}\text { Maximum interval between the cycles of the } \\
\text { standard mode of monitoring the state of } \\
\text { buildings, structures and adjacent soils }\end{array}$ & Biennially \\
\hline $\begin{array}{l}\text { Maximum interval between the cycles of the } \\
\text { permanent standard mode of monitoring the } \\
\text { temperature-humidity regime and ecological } \\
\text { state }\end{array}$ & Annually \\
\hline $\begin{array}{l}\text { Limit additional deformations of } \\
\text { foundations: }\end{array}$ & \\
$\begin{array}{l}\text { Relative difference in settlements } \\
\text { Maximum settlement, cm }\end{array}$ & 0.0004 \\
Curvature of the foundation footing, 1/m & $3 x 10-5$ \\
\hline
\end{tabular}

Periodic surveys are performed to update the data on the structural state of buildings. The surveys aim at:

- $\quad$ analysis of archival documents;

- visual examination;

- inspection of stone structures;

- $\quad$ inspection of wooden structures;

- $\quad$ evaluation of brickwork strength;

- $\quad$ evaluation of water content in walls;

- inspection of foundations.

- The following structures are subject to inspection:

- foundation soils, foundations;

- $\quad$ walls, columns, pillars;

- $\quad$ slabs and surfaces.

When performing construction and installation works in the immediate vicinity of buildings and structures, namely historical and cultural properties, excessive deformations must be eliminated in buildings being influenced by construction work [1]. For this purpose, prior to commencement of 
construction work, a geotechnical monitoring system should be created to ensure safety for buildings and structures being influenced by construction work [13].

The system of geotechnical monitoring must consist of a network of geotechnical equipment designed to perform manual or automated monitoring of the structural state of buildings. The geotechnical monitoring system aims at:

- considering the excesses of the criteria for safe construction work;

- $\quad$ analysis of the causes of excesses.

Since January 2017, the specialists from NGO "TyumGASU" have been monitoring the structural state of the Trinity Monastery and the building of former Commercial School. The procedure consists of the following stages:

1. Preparatory stage.

2. Main (working) stage.

The paper deals with the preparatory stage which includes:

a) installation of geodetic marks, crack meters and reflective marks in accordance with the developed and approved schemes; drilling of piezometric wells;

b) recording of "zero" readings of the installed equipment;

c) recording of level values of background vibrations resulting from transport and other sources at the site;

d) drawing up a technical statement (report) [2].

Geodetic marks are installed in the base course of buildings and structures to monitor extra settlements.

As a rule, settlement marks, spaced at $15 \mathrm{~m}$, are installed along the perimeter of buildings and structures at the points of internal walls abutment and in areas of unfavorable engineering and geological conditions. It is allowed to use steel bolts which are fixed in the walls in pre-made holes, e.g. with epoxy adhesive or dowels which are firmly embedded in the masonry (Fig. 3).
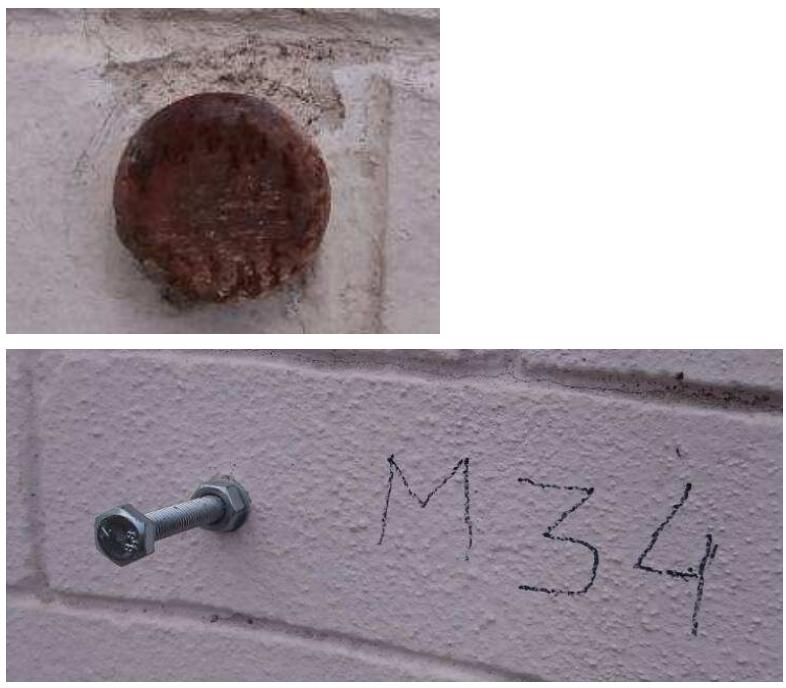

Fig. 3 Settlement marks
Ninety geodetic settlement marks and seventy reflective marks were installed at the listed buildings and sections of bank protection structures of the embankment. Schematic illustrations of geodesic settlement marks and reflective marks are given in Figures 4 and 5.

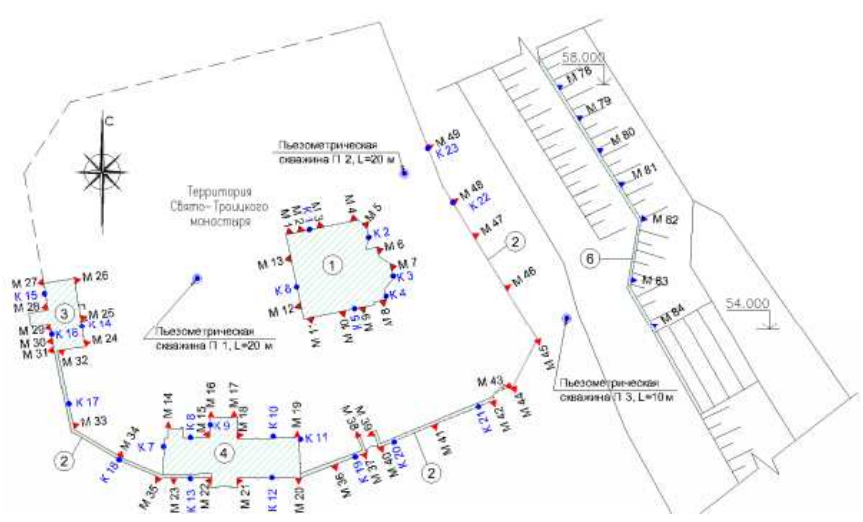

Fig.4. Schematic illustration of geodesic settlement marks at the Trinity Monastery

Fig. 4 shows the objects of monitoring: 1 - the Trinity Cathedral; 2 - the Monastery walls; 3 - the Rector's Corps; 4 the Church of Peter and Paul; 5 - bank protection structures of the embankment.

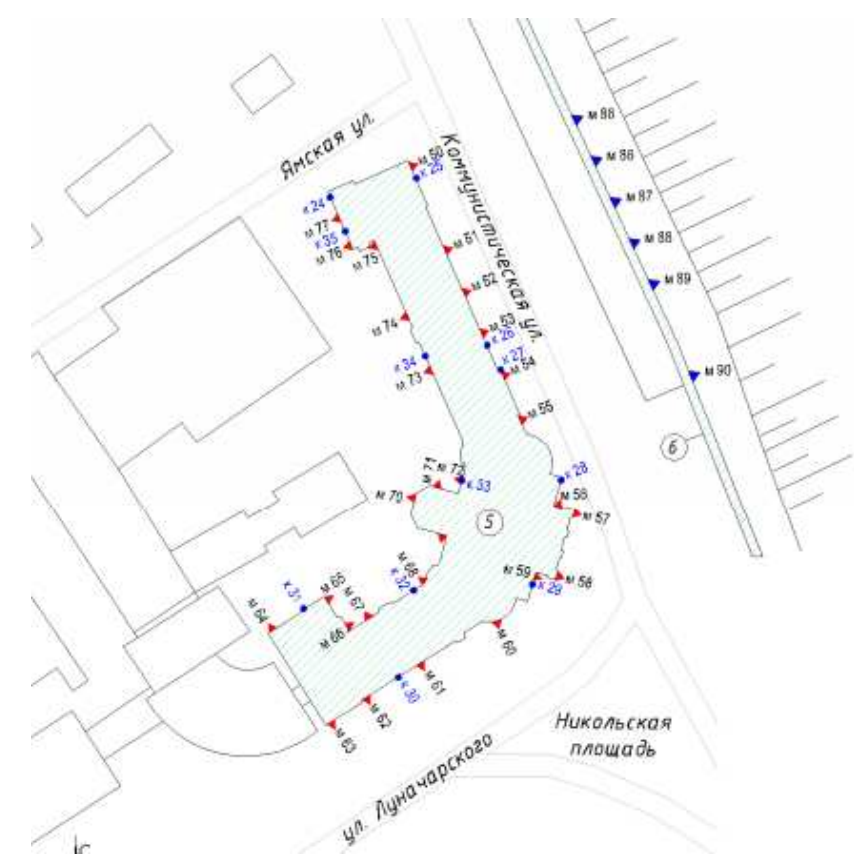

Fig.5. Schematic illustration of geodetic settlement marks at the Commercial School

Fig. 5 shows the following objects of monitoring: 5 - the building of Commercial School; 6 - bank protection structures of the embankment.

Geodetic monitoring of settlements in the building which was carried out from 26.11.2016 to 26.12.2016 resulted in the 
increase of foundation settlement exceeding the maximum allowable settlement for buildings of the 3rd category according to the structural state; this was observed on marks №. 46, №47, №80 and №81.

Observations were made by direct leveling using precision digital batter levels when the marks moved in relation to the initial observation. The difference between the elevation points of zero and subsequent measurement cycles makes it possible to analyze the absolute values of deformations and rate of their variations. The measurements with LeicaDNA03 batter level incorporating two invar three-meter rails were made at the Trinity Monastery and the building of former Commercial School (Fig. 6).

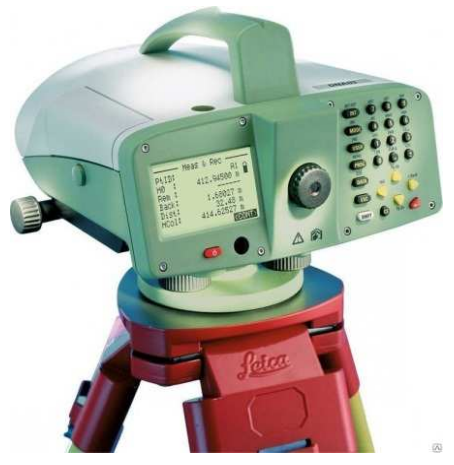

Fig. 6 Leica DNA03 batter level

Width of crack growth on the vertical and horizontal axes were observed using Mayak-ZI-2.2 crack meter (Fig. 7).

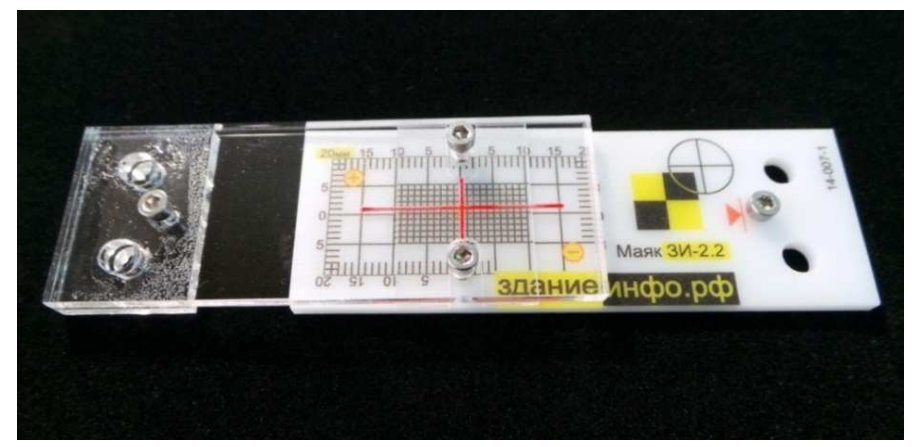

Fig. 7 Mayak-ZI-2.2

The crack meters were installed at places specified after the inspection of buildings. The scale division of Mayak-ZI2.2 working surface is $1 \mathrm{~mm}$; the range of observations along the $\mathrm{X}$-axis is $15+20 \mathrm{~mm}$, along the $\mathrm{Y}$-axis $-10+10 \mathrm{~mm}$. A total of 27 crack meters were installed.

When measuring crack width with crack meters for the period from 25.12.2016 to 25.01.2017, gain over $1 \mathrm{~mm}$ in the growth of crack width was revealed during the entire period of observation at crack meters No. 16 and 21.

To control extra tilts in the buildings under monitoring, reflective marks were installed on the walls (Fig. 8).

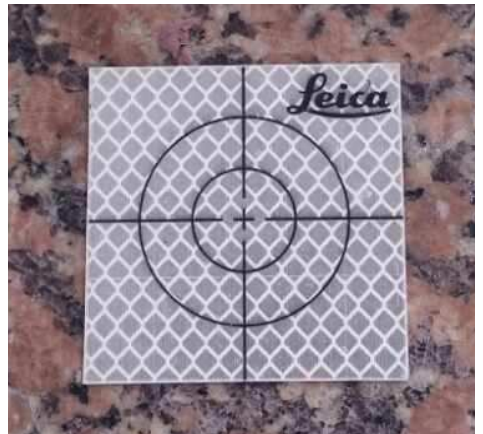

Fig. 8 Reflective mark

Observations were made with a tachymeter when the marks moved in relation to the initial observation.

When carrying out geodetic measurements of tilts with reflective marks for the period from 25.12.2016 to 25.01.2017, areas with extra tilts exceeding the ultimate limit values were revealed.

Hydrogeological monitoring is being performed at the area of the Trinity Monastery due to the unfavorable geotechnical conditions caused by: natural slope processes, regular breakages at the heating and water supply networks (the area is saturated with underground communications), unregulated discharge of utilities and regulated drainage of storm water which reduce the slope stability.

To monitor hydrogeological conditions, some piezometers were installed: three - at the area of the Trinity Monastery and two - at the area of the building of former Commercial School (Fig. 9, 10).

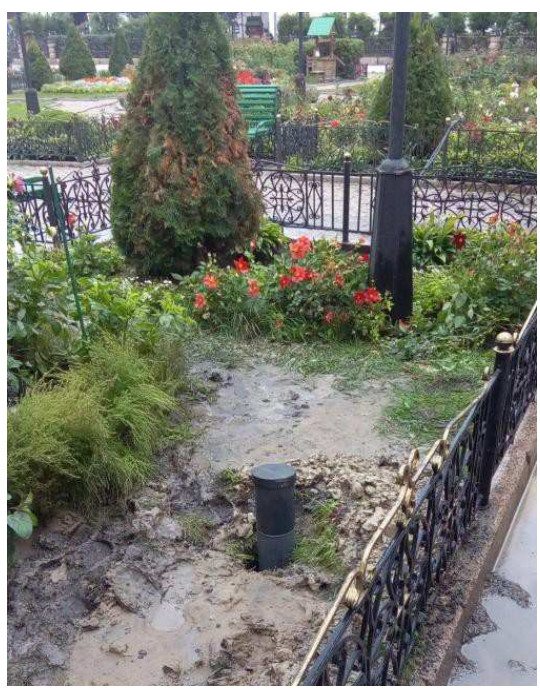

Fig. 9 Piezometric well

Variations in the groundwater level in the wells are determined with special water level indicators (Fig.11). 


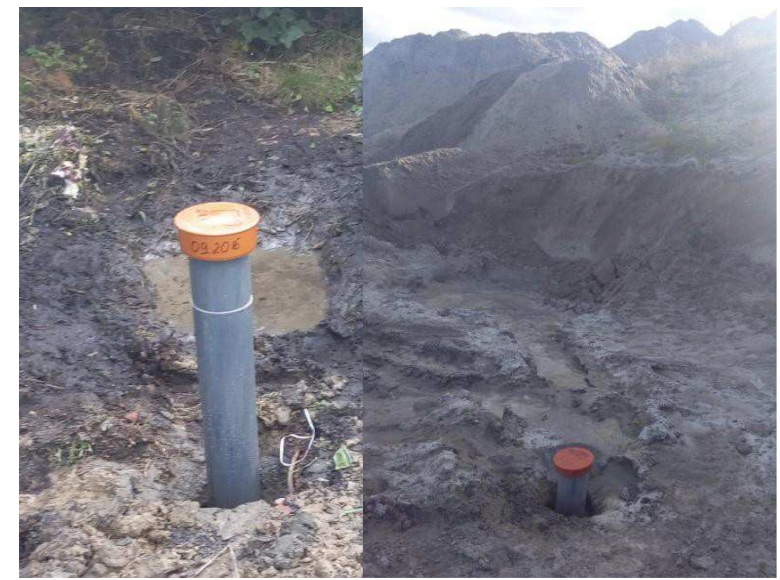

Fig. 10 Piezometric wells

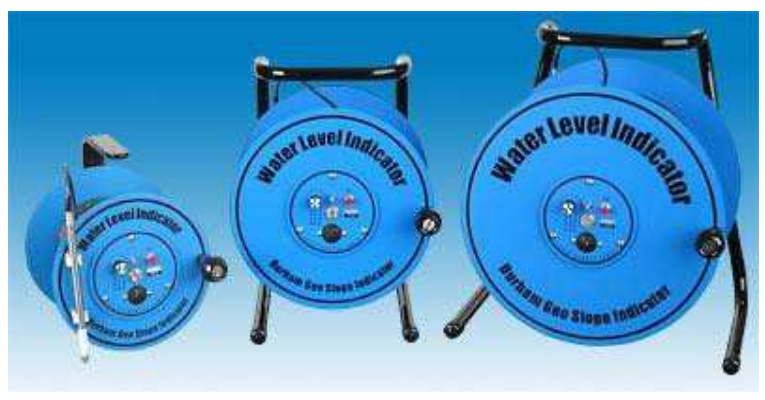

Fig. 11 Water level indicators

To record ground vibrations under dynamic effects from transport and other sources, a digital 1-class four-channel vibrometer - SVAN 948 (Fig. 12, a) and accelerometer D3143M1 (Fig. 12, b) are used for simultaneous measurement of vibrations along $\mathrm{X}, \mathrm{Y}$ and $\mathrm{Z}$ axes. a)

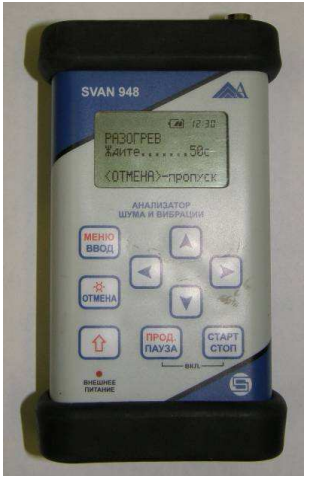

b)

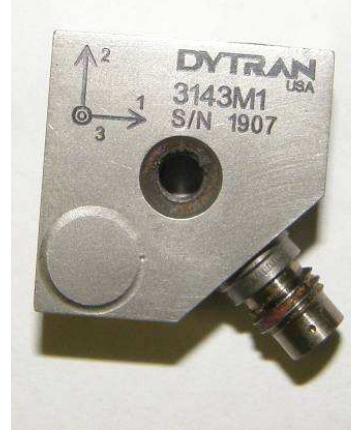

Fig. 12 Indicators to record ground vibrations under dynamic effects: $\mathrm{a}$ - noise and vibration indicator - SVAN 948; b - accelerometer D3143M1

Instrumental monitoring of the seismic effect is performed applying a multichannel method. This means that oscillations are recorded simultaneously at several points and several components. Thus, the seismogram registers oscillations on several tracks. This method makes it possible to compare ground movement at different zones in conjunction with building motion.

\section{CONCLUSION}

Preservation of historical, cultural and architectural monuments is undoubtedly one of the priorities of state policy. On the other part, improvement and development of the city provide for renovation of existing buildings and construction of new structures and engineering facilities. Thus, the need to monitor structural state of historical and cultural heritage sites becomes particularly important. Timely measures to identify and assess the influence of new construction on cultural heritage sites make it possible to preserve these buildings and improve urban environment.

The described observation and test methods help determine criteria for structural assessment of buildings being influenced by construction work.

The given methods make it possible to determine values of deformations, to assess structural state of the buildings and to take appropriate measures to prevent their further deterioration.

\section{References}

[1] Building Regulations: SP 22.13330.2011 Foundations of buildings and structures. Revised edition of SNiP 2.02.01-83*, M.: Ministry of Regional Development of Russia, 2011

[2] Technical statement No.5 on geotechnical monitoring of the listed buildings being influenced by construction work: "Strengthening and improving the slope of the right bank of the Tura River, III line". Tyumen: NPO "TyumGASU", 2017.

[3] V.Y. Timofeev, O.K. Masalsky, D.G. Ardyukov, A.V. Timofeev, "Local deformation and rheological parameters by measurements in talaya station gallery (Baikal region)," Geodynamics \& tectonophysics, vol.6, pp. 245-253, 2015.

[4] M.A. Lebedeva, V.A. Sankov, A.I. Zakharov, L.N. Zakharova, "Surface deformations near the Baikal-Amur railway from differential sar interferometry," Geodynamics \& tectonophysics, vol.7, pp. 315-328, 2016.

[5] A.G. Malkov, N.N. Kobeleva, "Systemic study on deformations of structures," XI Intern. Sci. Congress Interexpo GEO-Siberia-2015, vol.1, pp. 221-227, April 2015 [Geodesy, geoinformatics, cartography, mining geodesy, p. 237, 2015].

[6] A.G. Malkov, N.N. Kobeleva, "The development of a programme for monitoring precipitation structures based on system approach system study of deformations of structures," XII Intern. Sci. Congress Interexpo GEO-Sibiria-2016, vol.2, pp. 26-30, April 2016 [Geodesy, geoinformatics, cartography, mining geodesy, p. 177, 2016 ].

[7] V.G. Kolmogorov, "Possibility of studying deformation state of the Earth's surface from the results of repeated high-precision leveling ," Vestnik SSGA, vol. 1(17), pp. 9-14, 2012.

[8] M.J. Bryn, D.A. Afonin, N.N. Bogomolova, "Geodetic Monitoring of Deformation of Building Surrounding an Underground Construction ," Procedia Engineering, vol. 189, pp. 386-392, 2017.

[9] M.G. Mustafin, V.A. Valkov, A.I. Kazantsev, "Monitoring of Deformation Processes in Buildings and Structures in Metropolises," Procedia Engineering, vol. 189, pp. 729-736, 2017.

[10] O.C. Stepanova, "Analysis of geodetic monitoring techniques for deformations of the listed buildings," Mining Information-analytical Bulletin, vol.4, pp. 418-422, 2014.

[11] E.N. Hmyrova, O.G. Besimbaeva, G.E. Zhunusova, "Monitoring of structural state of the load-bearing structures in the Opera and Ballet Theatre in Astana," VIII Intern. Sci. Congress Interexpo GEO-Sibiria2012, vol. 1, pp.19-23, April 2012 [Geodesy, geoinformatics, cartography, mining geodesy, p. 267, 2012].

[12] A.A. Sholomickij, E.K. Lagutina, E.L. Soboleva, "The project of geodetic works for monitoring of buildings and structures in the aqua 
park "KVARSIS"," XII Intern. Sci. Congress Interexpo GEO-Sibiria2016, vol.1, pp.31-36, April 2016 [Geodesy, geoinformatics, cartography, mining geodesy, p. 244, 2016].

[13] GOST 31937-2011 Buildings and structures. Rules for inspection and monitoring of structural state, M.: Standartinform, 2014.
[14] GOST R 56198-2014 Monitoring of the structural state of the listed buildings. Immovable monuments. General requirements, $\mathrm{M}$ : Standartinform, 2015. 